Syncope

\section{A patient with recurrent syncope}

\section{S Zachariah, G K Davis}

Answers on $p 120$.

A 43 year old man presented to the accident and emergency department with a history of feeling light headed followed by loss of consciousness after he had just finished jogging. There was no associated chest pain, palpitations, or seizure activity. He admitted to feeling dizzy and presyncopal almost every time after performing any strenuous exercise. Physical examination and blood investigations including serum cardiac enzymes and troponin I were normal. His admission electrocardiogram (ECG) is shown in fig 1 .

\section{QUESTIONS}

(1) What does his ECG show?
(2) What other investigations would you consider and what might they show?

(3) What diagnoses would you consider?

(4) How would you treat this patient?

Postgrad Med J 2004;80:117.

doi: $10.1136 / \mathrm{pmi} .2003 .015610 \mathrm{q}$

.................

\section{Authors' affiliations}

S Zachariah, G K Davis, Aintree Cardiac Centre, University Hospital Aintree, Lower

Lane, Liverpool L9 7AL, UK

Correspondence to: Dr Davis; gershan.davis@aht.nwest.nhs.uk

Submitted 4 September 2002 Accepted 8 January 2003

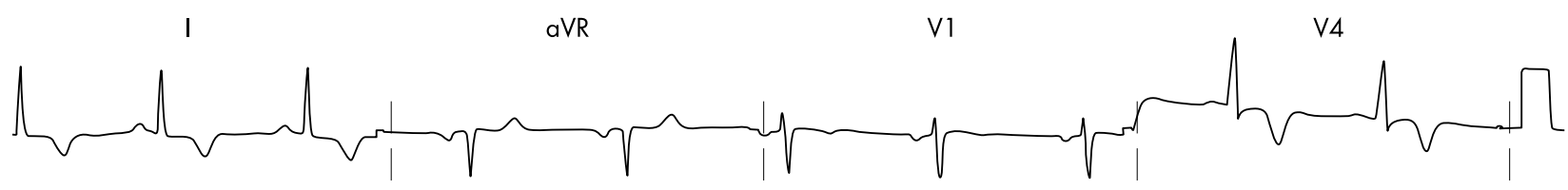

II

$\mathrm{aVl}$

V2

V5

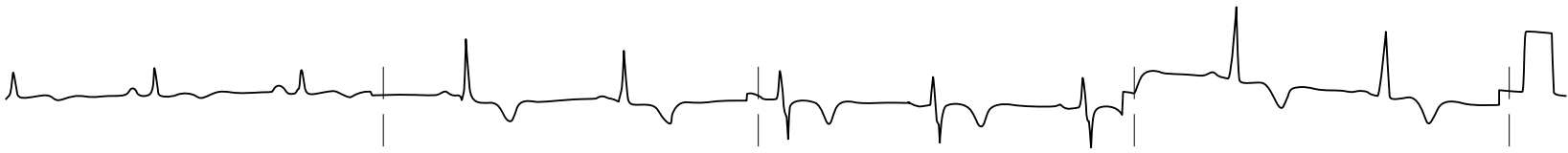<smiles>[SiH3]</smiles>

aVF

V3

V6

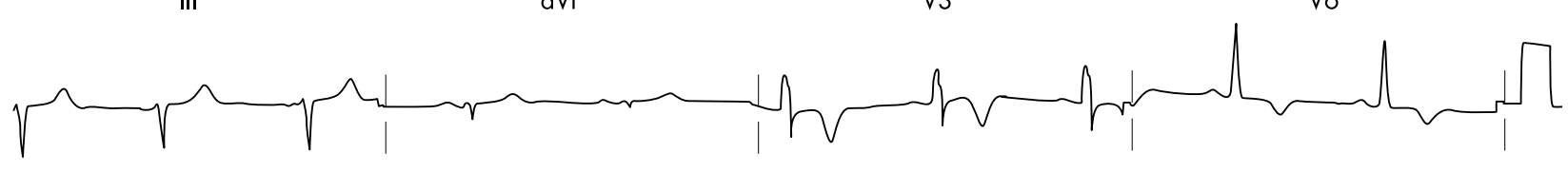

$25 \mathrm{~mm} / \mathrm{sec} ; 1 \mathrm{~cm} / \mathrm{mV}$

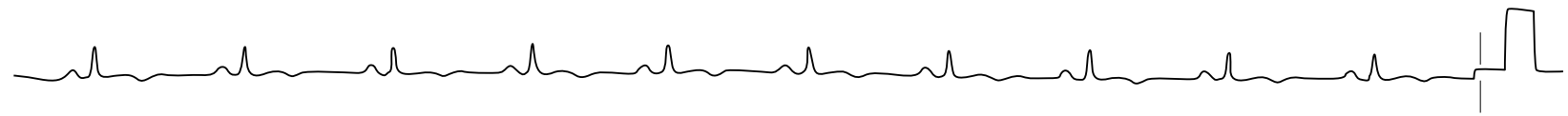

Figure 1 ECG on admission. 